\title{
An assessment on the parallel impacts of building information modeling and big data on project operation and maintenance
}

\author{
Masoud Shayganmehr ${ }^{1}$ and Ehsan Saghatforoush ${ }^{2 *}$ \\ ${ }^{1}$ Department of Information Technology Management, Tarbiat Modares University, Tehran, Iran \\ ${ }^{2}$ School of Construction Economics and Management, University of the Witwatersrand, \\ Johannesburg, South Africa
}

\begin{abstract}
Operation and maintenance challenges have always been pronounced in construction projects. Many solutions have been proposed to mitigate the common problems but the solution are not sufficient to get over the challenges, therefore, many software-based concepts such as Building Information Modeling have been unveiled to evaluate the construction prior to initiating the project and envision the potential challenges which exist on the way. For higher accuracy IT solutions can be accompanied with Building Information Modeling to leverage the performance and precision of modeling such as Big Data, data mining and even RFID tags, this paper aims to carry out an in-depth literature review on how BIM alongside with Big Data solutions have parallel impacts into higher efficiency and performance of operation and maintenance in construction projects.
\end{abstract}

\section{Introduction}

Many developing countries are moving toward industrialization, one of the most critical parts of these significant changes is pertaining to building industry which is likely to be enhanced by applying new technologies and new innovative approaches in the design and construction housing in order to accomplish their goals. The traditional practices and process should be changed for labor cost saving, time and cost of construction as well as reaching higher quality [1].

Construction industries still suffering from inefficient project delivery in time and cost, the vast majority of building projects are most likely to face up to exceeding budgets and deadlines. Moreover, greenhouse gas emission to the environment and consuming too much energy in comparison with other industries are astronomically high in both private and public sector [2]. Despite the overwhelming number of demand for construction, building and Maintenance still in the construction industry has always been treated so poorly, and management procedures which are conducted by contractors were below par and so weak. One of the common problems in building construction industry is a concrete problem which

\footnotetext{
* Corresponding author: ehsan.saghatforoush@,wits.ac.za
} 
has caused the collapse of many houses in Nigeria additionally the trace of failure investigation was so poor due to the absence of accurate data from other use cases in the country [3].

Architecture, Engineering, and Construction (AEC) industry have been looking for a solution to decrease the cost and time of delivery as well as increasing efficiency and productivity in projects, and BIM is taken an account as a great solution for fulfilling the needs [4]. One of the most significant breakthroughs in the AEC is Building Information Modeling (BIM) concept. BIM can simulate the virtual model of the building which contains precise information such as geometry, spatial relationships, geographic information, quantities, cost estimates, material inventories and project schedule to realize the building $[5,6]$.

BIM is seen as a model which contains all aspects of project in a virtual model which help all team members collaborate together more efficiently rather than traditional approach, therefore, all stakeholders can get involved in customizing any parts of the model to make it as accurate and precise as possible prior to starting the project physically [7]. BIM is more than just software; it can have a direct effect on workflow and project delivery [8].

Different verified studies have shown that BIM can save time and money; in this regard, four real case studies have been conducted in Hilton Inn, Savannah University, Atlanta Mansion, and Atlanta Building. All of the four case studies have practically proven that application of BIM can save money and time as well [9]. Through applying advanced analytics technologies, organizations can leverage their creative insights and gain many benefits in various fields such as e-commerce, e-government, science, health, and security [10]. Different industries can gain lots of benefits from big data; the value which they receive from big data depends on their strategic goal of their organizations [11]. Additionally, big data can provide more efficient and effective operation as well, such as appointing the right people for tasks and decreasing the errors and quality problems as well [12-14]. Big data can be defined in five main characteristics such as volume, variety, velocity, veracity, and value [15].

The vast majority of BIM is considered as a stand-alone system which is going to be run on a single computer which means that just a single user is capable of using such information. Therefore, the computing resources are going to be limited. As long as we experience exponential growth of data size and complexity it turns out to be difficult to handle such overwhelming massive amount of data on a single computer, creating a single format for all commercial BIM software is required to allow users to see various models created in them. Cloud Computing can provide access to the variety of resources for end users through the internet connection. Additionally, it can provide on-demand access to oodles of computing resources [16].

With the advent of new and complicated technology, BIM can be leveraged and amplified by IT-based analysis technique, before starting the building we do need to carry out accurate analysis on the collected data by big data and cloud computing, this cuttingedge technology can enhance the accuracy of the model through complicated algorithm analysis.

This research aims at raising the most common challenges which are most likely to take place in the construction industry and how these challenges have been mitigated by BIM over past years, additionally, we consider the role of big data in helping BIM to provide much more reliable and more accurate result for analyzing the design prior to doing building construction. 


\section{Literature review}

Different studies have been raised regarding the challenges in Operation and Maintenance (O\&M) of projects. Additionally, many of these problems were resolved through BIM, but there are numerous problems which have remained as essential challenges which have not been solved by BIM, in this regard, cloud-based big data is another helpful tool to mitigate the O\&M challenges alongside with BIM, our literature review is conducted in three different segments including O\&M challenges, BIM as well as Big Data.

\subsection{Operation and maintenance challenges}

Different studies have been conducted on common challenges in O\&M through case studies, common challenges which building contractors usually face up to during the construction project including: 1) Providing more transparency in construction projects; 2) Building a national construction authority; 3) Providing investment for enhancing worker's skills; and 4) Appropriate use of information and communication technology [2].

Another big challenge in O\&M is associated with delay, many construction projects tend to experience a long delay in delivering projects, this ubiquitous problems stems from various reasons, the most relevant reasons which cause to delay in delivering projects are financial problems, shortage of material on the site, poor site management, delay in delivering material, equipment and tools shortage, poor coordination, late decision making, late supervision, poor weather condition, transportation delay, poor economic condition and changes in law and regulation [17].

Reliable and regular communication between all stakeholders are taken into account as of the main challenges in O\&M, constant communication and collaboration can quickly enhance the performance in O\&M, but in the traditional method, communication and collaboration between stakeholders are not pronounced efficiently which is likely to lead to many prospective challenges [18].

Documented-based data gathering was the primary and core of traditional methods to keep and record all relevant data, this is considered as another challenge which hinders updating, therefore, all collected data are not so practical due to absence of being updated, as a result all collected data are less efficient and helpful as time goes by, keeping data updated is required digital-oriented formats otherwise, it is so time-consuming and impossible to have all the data updated, digital formats allow different software to keep the data updated in real-time as well as providing many value-added services [18-20].

\subsection{Building Information Modelling (BIM)}

BIM is defined as a digital tool which is applied through whole phases and steps of building construction industry in order to have better collaboration, communication, scheduling and visualization, BIM is a great tool to reform any potential errors which are prone to take place before initiating project [21]. The key benefits of BIM can be touched on such as 1) Easy and faster information sharing; 2) Fastidious analysis of proposal design prior to erecting the building; 3) Better understanding of proposal therefore better customer service is provided; 4) all digital product data can be applied for better facilities management [22].

Due to data fragmentation and absence of data integration during the lifecycle of the construction project, cloud-based BIM technology has been proposed to provide more consistency between gathered data in collaborative enterprises, and project data management is taken place by cloud-based BIM [23]. 
Facilities management is one of the central and core activity of construction industry which has been facilitated by BIM, but for better tracking of assets, a mobile-oriented BIM has been proposed to have real-time visualization of facilities which can take place by RFID tags attached to assets as well [24].

Another four main challenges which exist in the BIM and should be overcome are: 1) Recognition of relevant information for operational decision; 2) Customization of current BIM model; 3) Real-time data transferring into the BIM software and monitoring system; and 4) Decreasing uncertainty in incomplete building documentation [20].

\subsection{Big Data}

Based on our research there are a few numbers of research about how Big Data can make a strong contribution into enhancing BIM software, cloud-based framework storing, analyzing massive data collections in BIM as well as carrying out big data analysis techniques were introduced. Different Users can have access to the BIM software concurrently regardless of their location on the cloud-platform, and BIMCLOUD can analyze the distributed servers through Big Data technology [25].

Big data and spoken dialogue BIM system were proposed to capture structure and unstructured data knowledge which BIM was unable to capture unstructured data knowledge from building maintenance and refurbishment. The proposed system extract questions from various users than help them get their answers from the knowledge of previously done use cases. The system facilitates finding the answers of new questions facing in the maintenance and refurbishment [26].

Integration of big data and BIM was proposed on effective and optimized management of highway which is required variety of data from traffic and roadway data, in order to do so, creating a platform for data management is essential which can also provide more value based on collected data in lifecycle data management [27].

A new route of development was proposed to integrate BIM and Big Data, and they exceed the attention of BIM from building focus model to entire city model which cause BIM to demand Big Data analytics and applying tools such as machine learning, Artificial Intelligence [28].

Big Data analytics was suggested for construction waste minimization to empower the current BIM design software products which are unable to support construction waste minimization. Therefore, Big data can be aligned with BIM in order to get over construction waste minimization as well [29].

Different studies have conducted about embedding BIM software on the cloud services, the SOA4BIM model has proposed for accessing different devices and system to the BIM software on the web [30].

A framework has also been proposed for accessing to the central server which contains lots of installed packages for construction project lifecycle. Users can access the various installed software and BIM on the cloud platform by HTTP front [31].

Based on our the extensive literature review, the role of big data in BIM has not carried out so vehemently, the created data during O\&M projects are not utilized to do the useful and helpful analysis for enhancing the efficiency of building construction projects as well as getting over the common O\&M challenges.

\section{Methodology}

The applied methodology for this paper is depth e review on challenges on the maintenance and operation in the construction industry and how big data alongside BIM can enhance the maintenance and operation efficiency in construction industry, additionally, we enlighten 
the improvement of BIM with the help big data to provide more meticulous and real-time analysis on the data gathering.

This paper consists of three significant steps, in the first step, we carried out depth literature review to get a broad picture of the topic and easily spot the existing gaps [32], therefore, the conducted depth literature review help us identify common challenges in the O\&M building construction industry, in the second step, BIM was investigated to see its lacking in solving the challenges more effectively and how it can make a substantial contribution to mitigating such common challenges. In the third step, we consider soft computing such as BIG DATA in amplifying and leveraging the performance of BIM in resolving the common challenges.

\section{Results and discussion}

The common challenges which can take place in building construction industry are mentioned in Table 1, the research raised such the most invisible challenges in O\&M, the paper raised some existing challenges which have not yet been entirely solved with the help of building construction tools including BIM, therefore the research has aimed at highlighting the significant role of soft computing such as BIG data to overcome the challenges more effectively. Relations and interdependency between all stakeholders are always problematic, this issue has been mitigated with utilization of BIM but due to limitation of BIM in providing widespread collaboration has caused the problem to exist, Big Data and Cloud computing has come together to overcome the existing limitation in BIM and allow stakeholders to communicate and collaborate more smoothly [33]. Cloud computing allows users to communicate with each other remotely regardless of their location, and many users can receive service from a remote host as well as having a higher power in computing in comparison with single computer [34].

Documented-based exchange in traditional formats are very time-consuming and not precise, traditional information exchange is based on a pile of documents which allow stakeholders to share and exchange their information in O\&M but with the help of BIM and Cloud computing, information exchange has become real-time and so fast which has soothed the communication more effectively [19].

Massive amount of data are generated every day in O\&M which can provide an indepth understanding of facility management, such information never extracted and used in conventional method, therefore, with the help of cloud computing and big data are flowed without restriction and applied into extracting meaningful algorithm and value for better facility management as well $[25,35]$.

In order to see the relationships and value creation from soft computing and BIM in O\&M in building construction industry, Table 1 shows in details between all mentioned concepts.

Massive amount of data are generated during O\&M, such created information can be so useful for enhancing facility management and increasing operation efficiency, BIM somehow answered this significant challenges through collecting data on a single user who can help conduct analysis on potential design of building and predict prospective problems passively but this information is entirely limited to single users therefore, more stakeholder's involvement is required for more accuracy and efficiency, embedding BIM on Cloud-based Big Data can overcome the challenges by integrating between more stakeholders to get themselves engaged with the O\&M as well as applying strong big data technology to predict potential challenges in O\&M [25, 35].

High interdependency between stakeholders during O\&M projects requires a strong relationship which should facilitate the collaborations and communications between all players, absence of communicative and collaborative tools in O\&M projects is considered 
as one of the significant challenges, all traditional information exchange was documentedbased which hamper efficient collaboration. BIM has somehow mitigated the challenges and allow users to collaborate on the restricted virtual environment but broader and stronger communication is required which can take place with the cloud-based big data, it allows users regardless of their location to collaborate and communicate during the O\&M projects and work as a tool to bridge the physical gap which exists during the project $[18,19,34]$.

Cost prediction is a challenging task in building construction industry due to the absence of data and information availability, BIM can help contractor to predict cost based on just current data not the past data collection prior to initializing the project but due to limited data accumulation on BIM, Cloud-based big data can respond to this challenges more precisely by collecting widespread current and past information and data from unlimited stakeholders as well as using big data tools for more precise and accurate analysis $[18,25]$.

Table 1. Comparing between O\&M challenges, BIM, Big Data.

\begin{tabular}{|c|c|c|c|c|}
\hline z & $\begin{array}{l}\text { Operation and } \\
\text { Maintenance } \\
\text { challenges in } \\
\text { building industry }\end{array}$ & BIM & BIM Lacking & $\begin{array}{l}\text { How Big Data and } \\
\text { Cloud could } \\
\text { compensate the } \\
\text { lacking }\end{array}$ \\
\hline 1 & $\begin{array}{l}\text { Huge amount of data } \\
\text { are generated during } \\
\text { maintenance and } \\
\text { operations activities } \\
\text { which can make a } \\
\text { strong contribution } \\
\text { into facility } \\
\text { management [35]. }\end{array}$ & $\begin{array}{l}\text { To be able to do } \\
\text { analysis on the single } \\
\text { users collected data } \\
\text { and having different } \\
\text { formats of vendor's } \\
\text { software. } \\
\text { Unfriendly sharing } \\
\text { information [25]. }\end{array}$ & $\begin{array}{l}\text { All Data are user- } \\
\text { oriented and not } \\
\text { having any access to } \\
\text { collected data from } \\
\text { other users. } \\
\text { Users with different } \\
\text { software vendors are } \\
\text { not able to } \\
\text { communicate } \\
\text { together due to } \\
\text { having different } \\
\text { incompatible } \\
\text { vendor's data } \\
\text { software [25]. }\end{array}$ & $\begin{array}{l}\text { Having wide access to } \\
\text { the unlimited number } \\
\text { of Data and receiving } \\
\text { additional services on } \\
\text { cloud-based } \\
\text { environment [36]. } \\
\text { Single Formats for all } \\
\text { commercial software } \\
\text { (cloud computing) } \\
\text { which enable all users } \\
\text { regardless of their } \\
\text { vendor's software to } \\
\text { collaborate and } \\
\text { communicate } \\
\text { effectively [25]. } \\
\text { Soothing sharing } \\
\text { information by cloud } \\
\text { computing [34]. }\end{array}$ \\
\hline 2 & $\begin{array}{l}\text { Absence of } \\
\text { relationship between } \\
\text { parties due to } \\
\text { interdependencies and } \\
\text { large size of project } \\
\text { [18]. }\end{array}$ & $\begin{array}{l}\text { Users can } \\
\text { communicate and get } \\
\text { themselves involved in } \\
\text { a projects and apply } \\
\text { their own desired } \\
\text { changes [9]. }\end{array}$ & $\begin{array}{l}\text { Location restricts fast } \\
\text { changes in the BIM } \\
\text { software because all } \\
\text { user's systems are } \\
\text { passive and there is } \\
\text { no dynamic } \\
\text { collaboration } \\
\text { between systems } \\
\text { [37]. }\end{array}$ & $\begin{array}{l}\text { Regardless of your } \\
\text { location, stakeholders } \\
\text { can make desired } \\
\text { changes at any time } \\
\text { remotely [37]. }\end{array}$ \\
\hline 3 & $\begin{array}{l}\text { Traditional } \\
\text { information exchange } \\
\text { was documented- } \\
\text { based which cause to }\end{array}$ & $\begin{array}{l}\text { Different users can } \\
\text { communicate together } \\
\text { to get themselves } \\
\text { involved in the project }\end{array}$ & $\begin{array}{l}\text { The Customized data } \\
\text { by stakeholders are } \\
\text { not done in a real- } \\
\text { time and data }\end{array}$ & $\begin{array}{l}\text { User's customization } \\
\text { and changes in the } \\
\text { project are done in } \\
\text { real-time by cloud- }\end{array}$ \\
\hline
\end{tabular}




\begin{tabular}{|c|c|c|c|c|}
\hline 之) & $\begin{array}{l}\text { Operation and } \\
\text { Maintenance } \\
\text { challenges in } \\
\text { building industry }\end{array}$ & BIM & BIM Lacking & $\begin{array}{l}\text { How Big Data and } \\
\text { Cloud could } \\
\text { compensate the } \\
\text { lacking }\end{array}$ \\
\hline & $\begin{array}{l}\text { inefficient } \\
\text { collaboration [19]. }\end{array}$ & $\begin{array}{l}\text { and carry out } \\
\text { customization. }\end{array}$ & $\begin{array}{l}\text { synchronizing is } \\
\text { time-consuming due } \\
\text { to absence of Internet } \\
\text { communication for } \\
\text { collaboration [38]. }\end{array}$ & based technology [38]. \\
\hline 4 & $\begin{array}{l}\text { Huge amount of data } \\
\text { are accumulated every } \\
\text { day during operation } \\
\text { and maintenance } \\
\text { phase which can } \\
\text { provide deep } \\
\text { information about } \\
\text { facility management } \\
\text { [35]. }\end{array}$ & $\begin{array}{l}\text { Data are collected on } \\
\text { each user's system and } \\
\text { allow you to do } \\
\text { analysis. } \\
\text { Data analysis is } \\
\text { conducted on the } \\
\text { software based on the } \\
\text { collected data on the } \\
\text { user's system [25]. }\end{array}$ & $\begin{array}{l}\text { Data on a single } \\
\text { system are limited } \\
\text { due to absence of } \\
\text { internet } \\
\text { communication with } \\
\text { other users. } \\
\text { Data analysis is not } \\
\text { that much precise } \\
\text { due to the limited } \\
\text { size of collected data } \\
\text { [25]. }\end{array}$ & $\begin{array}{l}\text { Cloud-based } \\
\text { environment cause } \\
\text { accumulation of } \\
\text { massive data from } \\
\text { unlimited number of } \\
\text { users which pave the } \\
\text { way for big data } \\
\text { analysis. } \\
\text { Cloud-based } \\
\text { environment cause } \\
\text { presence of big data to } \\
\text { provide more } \\
\text { meticulous and } \\
\text { fastidious data analysis } \\
\text { [39]. }\end{array}$ \\
\hline 5 & $\begin{array}{l}\text { Cost prediction of } \\
\text { maintenance has } \\
\text { always been a big } \\
\text { challenge owing to no } \\
\text { analysis on the } \\
\text { collected data for } \\
\text { prediction because } \\
\text { maintenance cost has } \\
\text { always been based on } \\
\text { previous year plus } \\
\text { percentage [18]. }\end{array}$ & $\begin{array}{l}\text { Data Value is created } \\
\text { based on current } \\
\text { information and data } \\
\text { collection [25]. }\end{array}$ & $\begin{array}{l}\text { Historical data are } \\
\text { not considered in the } \\
\text { context of analysis } \\
\text { and value is just } \\
\text { created based on the } \\
\text { current data not past } \\
{[25] .}\end{array}$ & $\begin{array}{l}\text { Based on current and } \\
\text { past data accumulated, } \\
\text { the deep analysis is } \\
\text { going to be practiced; } \\
\text { therefore value is built } \\
\text { up based on past and } \\
\text { current data } \\
\text { accumulation [40]. }\end{array}$ \\
\hline 6 & $\begin{array}{l}\text { Lack of maintenance } \\
\text { software tools are so } \\
\text { challenging in making } \\
\text { decision [18]. }\end{array}$ & $\begin{array}{l}\text { Traditional BIM } \\
\text { software have different } \\
\text { features and analysis } \\
\text { methods which can do } \\
\text { analysis practices on } \\
\text { data accumulation } \\
\text { [41]. }\end{array}$ & $\begin{array}{l}\text { Lack of many value- } \\
\text { added services in } \\
\text { traditional BIM } \\
\text { service due to } \\
\text { absence of } \\
\text { interoperability [42]. }\end{array}$ & $\begin{array}{l}\text { More value-added } \\
\text { applications are } \\
\text { embedded on the } \\
\text { Traditional BIM } \\
\text { software for more } \\
\text { simulation and } \\
\text { analysis [23]. }\end{array}$ \\
\hline 7 & $\begin{array}{l}\text { Inability of detecting } \\
\text { value in huge amount } \\
\text { of data with different } \\
\text { formats and structure } \\
\text { such as picture, video } \\
\text { and so on }[43,44] \text {. }\end{array}$ & $\begin{array}{l}\text { BIM has a strong } \\
\text { capabilities in storing } \\
\text { huge amount of data } \\
\text { and doing some } \\
\text { analysis with the help } \\
\text { of big data [45]. }\end{array}$ & $\begin{array}{l}\text { Lack of capabilities } \\
\text { in extracting value } \\
\text { from unstructured } \\
\text { and inaccurate stored } \\
\text { data in Data analysis } \\
\text { in BIM [46]. }\end{array}$ & $\begin{array}{l}\text { DATA mining can } \\
\text { make a strong } \\
\text { contribution into } \\
\text { recognizing different } \\
\text { pattern and law which } \\
\text { have been hidden in } \\
\text { stored data [47]. }\end{array}$ \\
\hline
\end{tabular}




\begin{tabular}{|c|l|l|l|l|}
\hline \multicolumn{1}{|c|}{$\begin{array}{l}\text { Operation and } \\
\text { Maintenance } \\
\text { challenges in } \\
\text { building industry }\end{array}$} & BIM & BIM Lacking & $\begin{array}{l}\text { How Big Data and } \\
\text { Cloud could } \\
\text { compensate the } \\
\text { lacking }\end{array}$ \\
\hline 8 & $\begin{array}{l}\text { Inability to finding } \\
\text { appropriate } \\
\text { information for } \\
\text { improving efficiency } \\
\text { of the projects and } \\
\text { operational } \\
\text { performance [20]. }\end{array}$ & $\begin{array}{l}\text { To be able to do } \\
\text { analysis on the } \\
\text { designed model [38]. }\end{array}$ & $\begin{array}{l}\text { There is no limit to } \\
\text { the types of } \\
\text { information which } \\
\text { are infused into the } \\
\text { model but many of } \\
\text { this information are } \\
\text { unnecessary for day- } \\
\text { to-day operation } \\
\text { [20]. }\end{array}$ & $\begin{array}{l}\text { Carrying out on } \\
\text { relevant data which are } \\
\text { filtered and clustered } \\
\text { by machine learning } \\
\text { algorithms [25]. }\end{array}$ \\
\hline 9 & $\begin{array}{l}\text { Operation data in } \\
\text { digital formats are not } \\
\text { existed [20]. }\end{array}$ & $\begin{array}{l}\text { an organizational } \\
\text { standard BIM } \\
\text { Execution Plan are } \\
\text { utilized in providing } \\
\text { building construction } \\
\text { and renovation [20]. }\end{array}$ & $\begin{array}{l}\text { The size of data will } \\
\text { go exceedingly high } \\
\text { and data should be } \\
\text { recorded and no } \\
\text { online and streaming } \\
\text { analysis will take } \\
\text { place [20]. }\end{array}$ & $\begin{array}{l}\text { With the help big data } \\
\text { and MapReduce } \\
\text { method, we can } \\
\text { conduct analysis on the } \\
\text { huge amount of data } \\
\text { [25]. }\end{array}$ \\
\hline
\end{tabular}

Generated data during O\&M are collected on every single user to do analysis and prediction as well, but collected data on a single user is limited due to the absence of having communication with other users. Therefore, the ultimate result of this analysis is not as precise as on a single user. Cloud-based Big data can provide public communication on numerous user's systems, and the outcome of the analysis is based on more user's data which can lead to more reliable result $[25,35,39]$.

\section{Conclusions}

Maintenance and operation in building industry could be improved by cutting-edge IT technology when they align with BIM software, and the BIM software could help many construction contractors to assess those potential challenges which are most likely to take place during the project, many challenges importantly time and cost loss could be avoided. Moreover, data gathering on BIM software was completely limited due to single user data and not having access to a variety of other users' data, in this regard cloud technology was adopted to provide multi-lateral communication with other active users. BIM software cannot provide real-time analysis which can cause more accuracy; therefore, merging Big Data with BIM can provide more accurate and real-time analysis of collected data from users.

For future study, we recommend to follow up applying different tools of Big Data such as data mining in providing deep analysis on collected data for enhancing accuracy in provided results by BIM as well as overcoming existing challenges in O\&M which have not been resolved by BIM so far.

\section{References}

1. E. Ismail, Proc. of the 6th Asia Pacific Science and Technology Man. Seminar (2001)

2. A. Sawhney, R. Agnihotri, V.K. Paul, Built Env. Project and Asset Man. 4, 4 (2014) 
3. Ogunde, A. et al., J. of Build. Performance 8, 1 (2017)

4. S. Azhar, A. Nadeem, J.Y.N. Mok, B.H.Y. Leung, First International Conference on Constructiom in Developing Countries (ICCIDC-1) (2008)

5. B. Handbook, A guide to building information modeling for owners, managers, designers, engineers and contractors (Wiley, New York, 2008)

6. V. Bazjanac, Virtual building environments (VBE)-applying information modeling to buildings (2006)

7. J. Carmona, K. Irwin, BIM: Who, what, how and why. Building Operating Management (2007)

8. B. Hardin, BIM and construction management: proven tools, methods, and workflows (John Wiley \& Sons, Hoboken, 2009)

9. S. Azhar, Leadership and Man. in Eng. 11, 3 (2011)

10. T.H. Davenport, P. Barth, R. Bean, MIT Sloan Man. Rev. 54, 1 (2012)

11. A. Ghoshal, et al. The impact of business analytics strategy on social, mobile, and cloud computing adoption (2014)

12. H. Chen, R.H. Chiang, V.C. Storey, MIS Quarterly (2012)

13. T. Davenport, Harvard Business Rev. 84, 1 (2006)

14. A. McAfee, et al. Harvard Business Rev. 90, 10 (2012)

15. S.F. Wamba, et al. Int. J. of Prod. Economics 165 (2015)

16. P. Mell, T. Grance, The NIST definition of cloud computing (2011)

17. M.R.A.K.W. Alaghbari, A. Salim, Ernawati, Eng. Con. \& Architectural Man. (2007)

18. A. Alshehri, I. Motawa, S. Ogunlana, Int. J. of Innovation, Man. and Tech. 6, 3 (2015)

19. R. Volk, J. Stengel, F. Schultmann, Automation in Con. 38 (2014)

20. J. McArthur, Proc. Eng. 118 (2015)

21. M.F. Antwi-Afari, et al., Automation in Con. 91 (2018)

22. C.C. Innovation, Adopting BIM for facilities management: Solutions for managing the Sydney Opera House (Cooperative Research Center for Construction Innovation, Brisbane, 2007)

23. Y. Jiao, et al. Adv. Eng. Informatics 27, 2 (2013)

24. Y.C.S, Yu-Cheng Lin, Chen, Yen-Pei. The Scientific World J. (2014)

25. H.-M. Chen, K.-C. Chang, T.-H. Lin, Automation in Con. 71 (2016)

26. I. Motawa, Facilities 35, 13-14 (2017)

27. Z. Aziz, Z. Riaz, M. Arslan, Facilities 35, 13-14 (2017)

28. F.R. Correa, Proc. of $32^{\text {nd }}$ International Symposium on Automation and Robotics in Construction and Mining: Connected to the Future (2015)

29. M. Bilal, et al., Int. J. of Sust. Build. Tech. and Urban Dev. 6, 4 (2015)

30. R. Jardim-Goncalves, A. Grilo. Automation in Con. 19, 4 (2010)

31. C. Amarnath, A. Sawhney, J.U. Maheswari. Proc. of Information and Communication Technologies (WICT) (2011)

32. T. Ferfolja, L. Burnett, Getting started on your literature review: A general guide for postgraduate research students. (The Learning Centre UNSW, Sydney, 2002)

33. I.M.A. Ayman, S. Ogunlana, The Common Problems Facing the Building Maintenance Departments (2017) 
34. L.M. Vaquero, et al., ACM SIGCOMM Computer Communication Rev. 39, 1 (2008)

35. Y. Peng, et al. Build. and Env. 126 (2017)

36. F. Chang, et al. ACM Trans. on Computer Sys. (TOCS) 26, 2 (2008)

37. M. Ilich, B. Becerik, B. Aultman, The Construction Zone 6, 3 (2006)

38. E. Alreshidi, M. Mourshed, Y. Rezgui, J. of Computing in Civ. Eng. 30, 4 (2015)

39. J. Cohen, et al., Proc. of the VLDB Endowment 2, 2 (2009)

40. D. Talia, Computer 46, 5 (2013)

41. F. Abanda, J. Tah, F. Cheung, J. of Build. Eng. 14 (2017)

42. A. Grilo, R. Jardim-Goncalves, Automation in Con. 19, 5 (2010)

43. H. Liu, M. Al-Hussein, M. Lu, Automation in Con. 53 (2015)

44. K.K. Han, M. Golparvar-Fard, Automation in Con. 73 (2017)

45. M. Bilal, et al., J. of Build. Eng. 6 (2016)

46. K. Orr, et al. Proc. of Construction Research Congress 2014: Construction in a Global Network (2014)

47. J.R. Lin, et al. Computer Aided Civ. and Infrastr. Eng. 31, 1 (2016) 